\title{
LH Measurements by in Vitro Bioassay and a Highly Sensitive Immunofluorometric Assay Improve the Distinction between Boys with Constitutional Delay of Puberty and Hypogonadotropic Hypogonadism
}

\author{
ANNE-MAARIT HAAVISTO, LEO DUNKEL, KIM PETTERSSON, AND ILPO HUHTANIEMI \\ Department of Physiology [A.-M.H., I.H.], University of Turku, Turku, Children's Hospital [L.D.], University of
}

Helsinki, Helsinki, and Pharmacia-Wallac [K.P.], Turku, Finland

\begin{abstract}
The basal and gonadotropin-releasing hormone (GnRH) stimulated levels of $\mathrm{LH}$ were measured in 21 boys with delayed puberty using conventional RIA, mouse interstitial cell in vitro bioassay (B-LH), and a highly sensitive immunofluorometric method (F-LH). On the basis of subsequent clinical follow-up, the subjects were diagnosed as idiopathic constitutional delay of puberty $(\mathrm{CD}, n=13)$ or hypogonadotropic hypogonadism $(H H, n=8)$. The basal RIA LH levels were similar in the two diagnostic groups $(\mathrm{HH}, 2.92 \pm 0.76, \mathrm{CD} 3.53 \pm 1.37$ IU/L). In contrast, the mean basal B-LH was significantly lower in boys with $\mathrm{HH}$ than with $\mathrm{CD}(1.10 \pm 0.45$ versus $2.91 \pm 1.23 \mathrm{IU} / \mathrm{L} ; p<0.01)$. A similar finding was made by F-LH measurements which were clearly lower in the $\mathrm{HH}$ than the $\mathrm{CD}$ group $(0.073 \pm 0.04$ versus $1.71 \pm 0.97$ IU/L, $p<0.01)$. Also upon GnRH stimulation $(3.5 \mu \mathrm{g} / \mathrm{kg}$ i.v.), the distinction between the $\mathrm{CD}$ and $\mathrm{HH}$ groups was better with the B-LH and F-LH measurements. The basal $B / I$ ratio of the $C D$ group $(0.90 \pm 0.43)$ was more than that of the HH group $(0.42 \pm 0.25, p<0.01)$ and this ratio increased significantly (more than 2 -fold, $p<0.01$ ) during GnRH stimulation in the CD group, but not in the $\mathrm{HH}$ patients. Such differences were not found between the $B / F$ ratios of the $\mathrm{CD}$ and $\mathrm{HH}$ groups. Measurements of basal and GnRH stimulated B- and F-LH levels clearly improved the distinction between $\mathrm{CD}$ and $\mathrm{HH}$ in comparison to the conventional RIA method, due to the low sensitivity and likely cross-reactions with some non-LH constituents of serum in the latter assay. This problem is, to a great extent, eliminated by better sensitivity and specificity of B-LH and F-LH measurements. For the same reasons, the difference in $\mathrm{B} / \mathrm{I}$ ratios between the $\mathrm{CD}$ and $\mathrm{HH}$ samples, and the increased $B / I$ ratio after $G n R H$ stimulation in the $C D$ group, were not observed in $B / F$ ratios. In conclusion, the measurements of basal and GnRH-stimulated concentrations of serum B-LH and F-LH clearly improve the differential diagnostics between $\mathrm{CD}$ and $\mathrm{HH}$. The discrepancies measured between the $B / I$ and $B / F$ ratios in these samples call for reevaluation of the bio/immuno ratios of circulating LH. (Pediatr Res 27: 211-214, 1990)
\end{abstract}

Abbreviations

B/F ratio, ratio of serum B-LH/F-LH concentrations $B / I$ ratio, ratio of serum B-LH/I-LH concentrations

Received June 2, 1989; accepted September 22, 1989.

Correspondence Dr. Ilpo Huhtaniemi, Department of Physiology, University of Turku, Kiinamyllynkatu 10, SF-20520 Turku, Finland.

Supported by research contracts from The Academy of Finland and The Finnish Life and Pension Insurance Companies, and by grants from The Sigrid Jusélius Foundation and the Clinical Chemistry Research Foundation.

\section{B-LH, bioactive LH}

$\mathrm{CD}$, constitutional delay of puberty

F-LH, immunoreactive LH measured by immunofluorometric assay

GnRH, gonadotropin-releasing hormone

hCG, human chorionic gonadotropin

HH, hypogonadotropic hypogonadism

I-LH, immunoreactive $\mathrm{LH}$ measured by radioimmunoassay $\mathrm{CV}$, coefficient of variation

$\mathrm{CD}$ and $\mathrm{HH}$ pose a diagnostic problem in pediatric endocrinology. This differentiation is important for prognostic reasons and to avoid too long androgen treatment of children with CD. No hormonal measurement has thus far proven to be absolutely reliable in discriminating the two conditions $(1,2)$. Basal levels of immunoreactive LH and FSH show no clear differences (35), and even after stimulation tests with GnRH and hCG some overlap remains. In many cases the final diagnosis must await outcome of the clinical follow-up (3-5). Some information is available on discordant activation of the pituitary secretion of immunoreactive and bioactive $\mathrm{LH}$ during normal puberty, with a trend toward increase in the $\mathrm{B} / \mathrm{I}$ ratio of $\mathrm{LH}$ as puberty advances (6-12). These findings are corroborated by findings in adults with hypogonadotropic hypogonadism, in which the $\mathrm{B} / \mathrm{I}$ ratio is suppressed $(13,14)$. However, the recently developed highly sensitive immunometric measurements of gonadotropins $(15,16)$ have disclosed quite different data on the quantitative changes of serum gonadotropins during puberty, and their value has not yet been tested in the diagnostics of pubertal disorders. We therefore decided to compare the measurements of LH by conventional RIA, in vitro bioassay, and a highly sensitive immunofluorometric assay in boys with $\mathrm{CD}$ and $\mathrm{HH}$. The results demonstrate that both of the latter techniques improve discrimination between the two diagnostic groups.

\section{MATERIALS AND METHODS}

Patients. A total of 21 prepubertal boys, referred to the hospital because of delayed pubertal development or suspicion of gonadotropin deficiency, was studied. Data on the stage of maturation of the boys are presented in Table 1 . On subsequent clinical follow-up for at least $5 \mathrm{y}, 13$ of the boys developed normal spontaneous puberty, and were classified as CD. The diagnostic criteria of this group were spontaneous puberty appearing more than 2 y later than average, but progressing normally, and testis 
size appropriate for bone age $(17,18)$. The boys were followed up until at least full genital stage 4 (including normal testis growth) (19) for clinical confirmation of diagnosis. Eight of the boys were diagnosed as $\mathrm{HH}$. The diagnostic criterion was a prepubertal testis size at bone age more than $13.0 \mathrm{y}$ or testis size less than mean $-2 \mathrm{SD}$ of the normal boys at later bone age (17). Of the $\mathrm{HH}$ patients, four were subsequently diagnosed as Kallmann's syndrome, one as Prader-Willi syndrome, and three remained as idiopathic. The clinical diagnostics of these patients are described in more detail previously (5), where also some of the I-LH data were presented. None of the boys had received any androgen therapy before the study. At the time of the GnRH challenge tests, the stage of pubertal development, in particular that of bone age, of the boys was similar in the two groups (Table 1).

Methods. The GnRH challenge test was performed by injecting $3.5 \mu \mathrm{g} / \mathrm{kg}$ body wt of GnRH (Relefact, Hoechst, Frankfurt am Main, F.R.G.) as a 1-min i.v. injection at 0850-0900 h. Venous blood samples were obtained at $-20,0,20,30,60$, and $120 \mathrm{~min}$, and stored at $-70^{\circ} \mathrm{C}$ until analyzed.

The I-LH was measured by a double antibody RIA (reagents donated by NIADDK, NIH, Bethesda, MD) and the results were expressed in IU/L in terms of the 1st International Reference Preparation of human pituitary gonadotropins (68/40). The intra- and interassay CV of the method were 9 and $13 \%$, respectively, and the sensitivity of the assay was $1.9 \mathrm{IU} / \mathrm{L}$.

F-LH was measured using the time-resolved immunofluorometric assay technique (Delfia, Pharmacia-Wallac Oy, Turku, Finland) essentially as described recently by Apter et al. (16). The intra- and interassay $\mathrm{CV}$ of the method were less than $5 \%$, and the sensitivity was $0.02 \mathrm{IU} / \mathrm{L}$.

$\mathrm{B}-\mathrm{LH}$ was measured by the mouse interstitial cell in vitro bioassay, described by van Damme et al. (20), with some modifications (21). Each assay tube contained about 50000 interstitial cells in a volume of $100 \mu \mathrm{L}$ medium 199 (supplemented with 20 $\mathrm{mmol} / \mathrm{L} \mathrm{N}$-2-hydroxyethylpiperazine- $\mathrm{N}^{\prime}$-2-ethanesulfonic acid, $0.1 \mathrm{mmol} / \mathrm{L} 1$-methyl-3-isobutylxanthine, $10^{5} \mathrm{IU} / \mathrm{L}$ heparin, and $0.1 \% \mathrm{BSA}, \mathrm{pH} 7.4$ ) and of a $100 \mu \mathrm{L}$ aliquot of a standard or unknown serum dilution. The serum samples were diluted, on the basis of the expected LH levels, either 1:10, 1:30, 1:100, or 1:300 with the supplemented medium 199, and at least two dilutions per sample were analyzed in triplicate. The standards were diluted in the same medium, and LH-free serum was added to them and the higher serum dilutions to adjust the serum content of each assay tube to a constant $5 \%$. The LH-free serum was prepared from male peripheral serum by immunoadsorption to microtiter wells (anti-hLH Microtitration Strips from a Delfia hLH Kit, Pharmacia-Wallac Oy) coated with a MAb to the $\beta$ subunit of LH. This treatment removed more than $98 \%$ of the LH immunoreactivity present in the serum samples (21). By this procedure it was possible to obtain parallel dose response curves of the standards and serum dilutions in the bioassay. The sensitivity of the assay was $0.3-0.5 \mathrm{IU} / \mathrm{L}$, and the intra- and interassay $\mathrm{CV}$ less than 5 and $10 \%$, respectively. The end-point of the bioassay, testosterone production of the mouse interstitial cells,

Table 1. Chronologic and bone age, testis size, and pubertal stage of the patient groups with $C D(n=13)$ and $H H(n=8)$ $($ mean $\pm S D)$

\begin{tabular}{lccc}
\hline & $\mathrm{CD}$ & $\mathrm{HH}$ \\
\hline Chronologic $(\mathrm{y})$ & & $15.8 \pm 1.3$ & $16.6 \pm 7.2$ \\
Bone age (y) & & $13.2 \pm 1.0$ & $13.1 \pm 2.2$ \\
Testis size (mL) & & $5.3 \pm 3.0$ & $1.7 \pm 0.7^{*}$ \\
Genital stage† (no. of patients) & $\mathrm{G} 1$ & 1 & 5 \\
& $\mathrm{G} 2$ & 10 & 3 \\
& $\mathrm{G} 3$ & 2 & 0 \\
\hline
\end{tabular}

${ }^{*} p<0.01$ versus the $\mathrm{CD}$ group.

$\dagger$ Boys at G1 had prepubertal testicular volume $(<2.2 \mathrm{~mL})$. was measured in the incubation media by a direct RIA as described (22).

Student's $t$ test was used for comparisons of two means, and one-way analysis of variance followed by Duncan's new multiple range test, for multiple comparisons. The testis volumes were compared using the Mann-Whitney U test. A $p$ value of less than 0.05 was chosen as the limit of statistical significance. The study was approved by the Ethical Committee of the Children's Hospital, University of Helsinki.

\section{RESULTS}

The basal levels of LH (means of the -20- and 0-min samples) differed between the three assay methods used (Fig. $1 A$ ). No difference was found in basal I-LH levels between the CD $(n=$ $13)$ and $\mathrm{HH}(n=8)$ groups $(3.53 \pm 1.37$ and $2.92 \pm 0.76 \mathrm{IU} / \mathrm{L}$, respectively; mean $\pm \mathrm{SD}$ ). In contrast, $\mathrm{B}-\mathrm{LH}$ of the $\mathrm{CD}$ group $(2.91 \pm 1.23 \mathrm{IU} / \mathrm{L})$ was significantly higher than that of the $\mathrm{HH}$ group $(1.10 \pm 0.45 \mathrm{IU} / \mathrm{L})(p<0.01)$. The difference between the two groups was even more (more than 20 -fold) in the F-LH measurements $(\mathrm{CD} 1.71 \pm 0.97 \mathrm{IU} / \mathrm{L} ; \mathrm{HH} 0.073 \pm 0.04 \mathrm{IU} / \mathrm{L}$, $p<0.01$ ).

The maximal GnRH-stimulated levels of I-LH, B-LH and F$\mathrm{LH}$ remained low, less than $10 \mathrm{IU} / \mathrm{L}$, in seven of the eight subjects of the HH group (in all eight when measured by F-LH), but increased clearly in all subjects of the CD group (B-LH more than $15 \mathrm{IU} / \mathrm{L}, \mathrm{I}-\mathrm{LH}$ and F-LH more than $10 \mathrm{IU} / \mathrm{L}$ ) (Fig. $1 B$ ). The difference between low and high responses was greatest in the bioactivities, and only one of the $\mathrm{HH}$ subjects had a response reaching the range of the $\mathrm{CD}$ group. The F-LH assay was the only method where no overlap existed between stimulated levels of the two groups. The I-LH measurements were clearly worse in this respect, because both the low $\mathrm{CD}$ and the high $\mathrm{HH}$
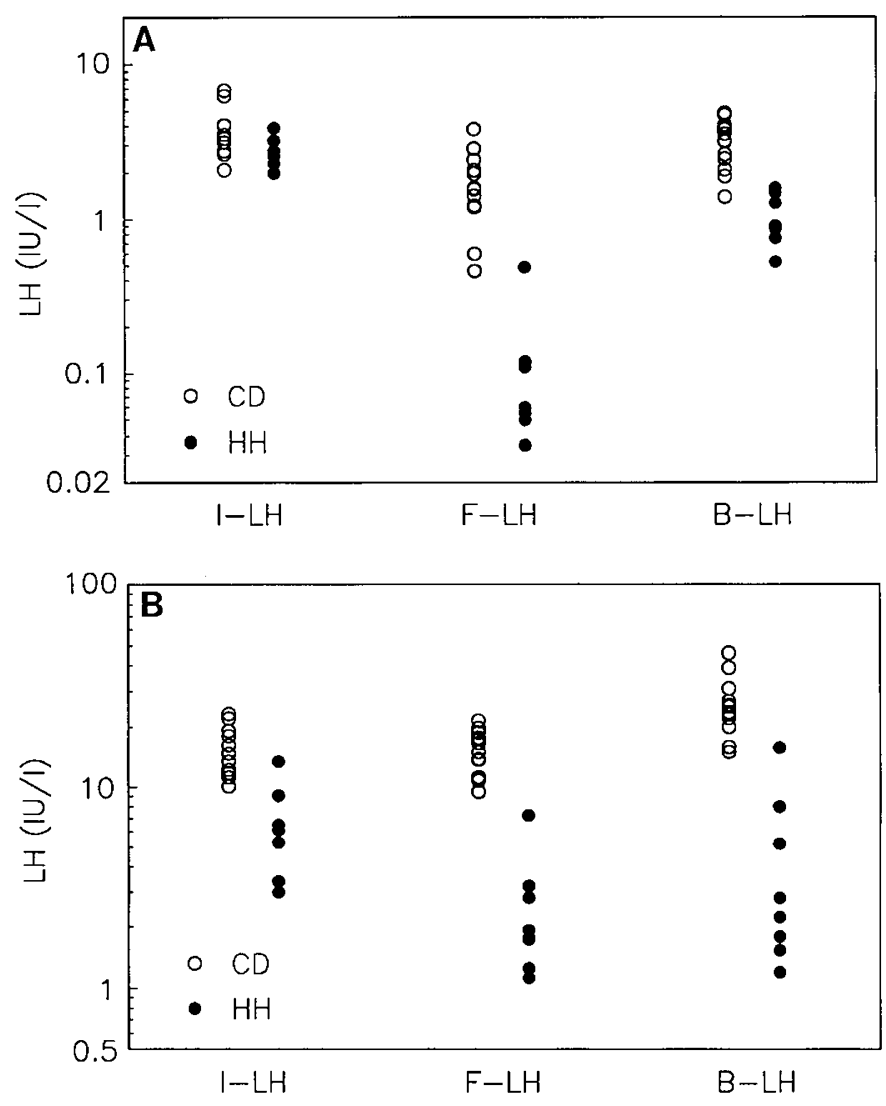

Fig. 1. Basal $(A)$ and maximally GnRH-stimulated $(B)$ levels of $\mathrm{LH}$ measured by $\mathrm{I}-\mathrm{LH}$, highly sensitive $\mathrm{F}-\mathrm{LH}$, and in vitro $\mathrm{B}-\mathrm{LH}$ in 13 patients with $\mathrm{CD}$ (open symbols) and eight patients with $\mathrm{HH}$ (closed symbols). 
responses to $\mathrm{GnRH}$ overlapped at a concentration of about 10 IU/L.

Time courses of the compiled LH responses to GnRH stimulation are shown in Figure 2. The increases in B-LH and F-LH were higher than those of I-LH, and the former levels stayed up longer. Clearly higher responses to the releasing hormone stimulation were seen in the CD than $\mathrm{HH}$ group in all three measurements. No differences in LH responses were found in either group according to bone age or stage of puberty or within the $\mathrm{HH}$ group between the different diagnoses (results not shown).
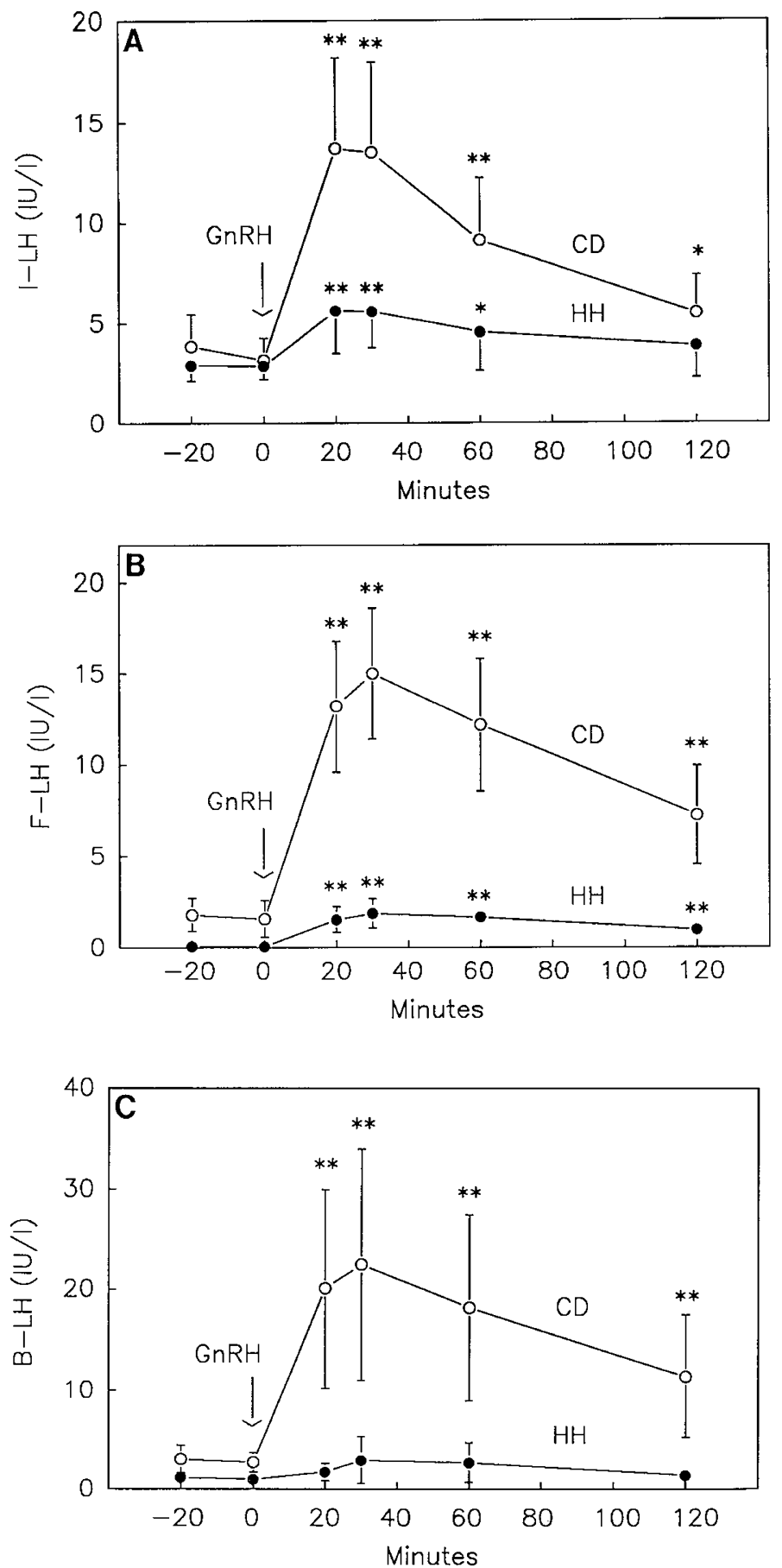

Fig. 2. Compiled $\mathrm{LH}$ responses (mean $\pm \mathrm{SD}$ ) of the patients with $\mathrm{CD}$ (open symbols) and HH (closed symbols) to GnRH stimulation. The ILH levels are $A$, the F-LH levels in $B$, and those measured by in vitro B$\mathrm{LH}$ in the $C$. If no error bars are shown, they are within the symbols. The asterisks indicate significant changes from the -20 and 0 min levels $\left({ }^{*} p<0.05 ;{ }^{* *} p<0.01\right)$.
The $\mathrm{B} / \mathrm{I}$ and $\mathrm{B} / \mathrm{F}$ ratios of the basal and $\mathrm{GnRH}$-stimulated CD and $\mathrm{HH}$ samples are shown in Figure 3 . The basal B/I ratio was about 2 -fold higher in the $\mathrm{CD}$ than $\mathrm{HH}$ group $(0.90 \pm 0.43$ versus $0.43 \pm 0.27, p<0.01$ ), and increased in the former group more than 2-fold after GnRH stimulation $(p<0.01)$. No change was observed after the releasing hormone in the $\mathrm{HH}$ group. The $\mathrm{B} / \mathrm{F}$ ratios were very different. This ratio was basally $1.99 \pm 0.65$ in the CD group and it was unaffected by the releasing hormone. In the $\mathrm{HH}$ group, a very high $\mathrm{B} / \mathrm{F}$ ratio (about 15 ) was measured in the basal HH samples. After $\mathrm{GnRH}$, it decreased to a level of about 1.7, and was thereafter indistinguishable for the CD group.

\section{DISCUSSION}

Our results clearly demonstrate the benefits of improved assay sensitivity and specificity, as offered by F-LH and B-LH measurements, in discriminating $\mathrm{CD}$ and $\mathrm{HH}$. Admittedly, the patient groups studied were somewhat heterogenous in terms of their chronologic age, testis size, and stage of puberty. Especially the larger testis volume in boys with CD suggests that the gonadotropin priming may have been different between the groups already before the time of testing. However, the main point of ours is clear, i.e. although the $\mathrm{CD}$ and $\mathrm{HH}$ groups could not be discriminated by conventional measurements of $\mathrm{I}-\mathrm{LH}$, the measurements of B-LH and F-LH brought about clear distinction between them.

The difference between the low and high post-GnRH levels was greater in the B-LH and F-LH than the I-LH measurements. Only one of the eight $\mathrm{HH}$ cases showed a B-LH response (and none, when assessed by F-LH) within the $\mathrm{CD}$ range. In contrast,
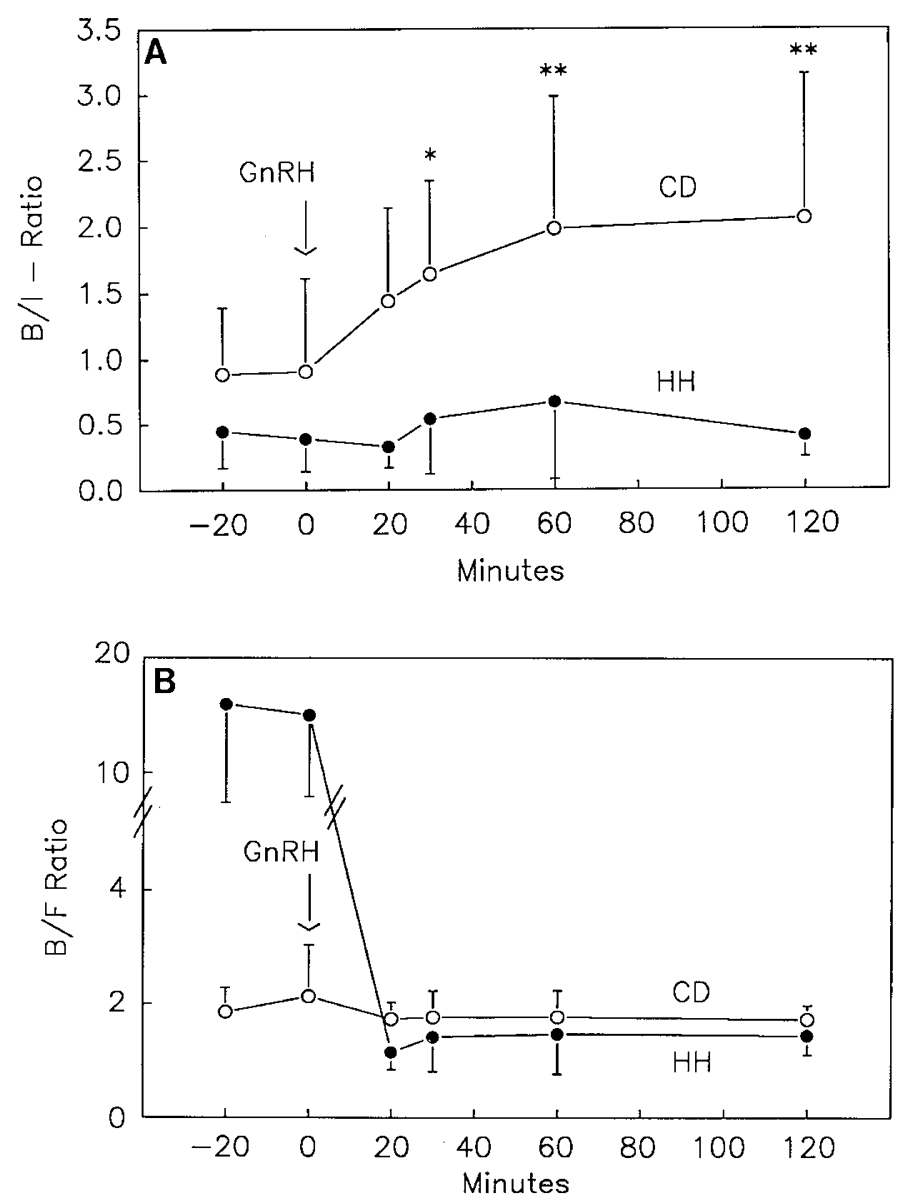

Fig. 3. The $\mathrm{B} / \mathrm{I}(A)$ and $\mathrm{B} / \mathrm{F}(B)$ ratios of the $\mathrm{LH}$ levels measured in the $\mathrm{CD}$ (open symbols) and $\mathrm{HH}$ (closed symbols) groups during $\mathrm{GnRH}$ stimulation (mean $\pm \mathrm{SD}$ ). The asterisks in the $\mathrm{B} / \mathrm{I}$ panel indicate differences from the -20 and 0 min levels $\left({ }^{*} p<0.05 ;{ }^{* *} p<0.01\right)$. 
the I-LH responses of the two groups were much closer. Because the final diagnosis was in each case based on clinical signs and follow-up, the aberrant response found in one subject of the $\mathrm{HH}$ group may best highlight the heterogenous nature of this clinical condition. It is of clinical importance that none of the $C D$ patients would have been falsely diagnosed as $\mathrm{HH}$ with the present tests, and subjected to unnecessarily long hormone treatment. Such a distinction could not have been done with the ILH measurements.

The $\mathrm{B} / \mathrm{I}$ ratio of $\mathrm{LH}$ was higher in the $\mathrm{CD}$ than the $\mathrm{HH}$ group, and it increased during GnRH stimulation only in the former group. The $\mathrm{B} / \mathrm{I}$ ratio of $\mathrm{LH}$ increases also during progression of normal puberty $(6-12)$. The response of the $C D$ group is in agreement with previous findings on increased $\mathrm{B} / \mathrm{I}$ ratio during stimulation of the adult pituitary by endogenous and exogenous GnRH $(14,23-25)$. The etiology of $\mathrm{HH}$ is heterogenous $(26,27)$, but a common factor may nevertheless be the lack of sufficient hypothalamic GnRH secretion. In adults, such a condition (e.g. after long term treatment with GnRH agonist) is related to decreased B/I ratio of circulating $\mathrm{LH}$ (27-29). Inasmuch as the acute $\mathrm{GnRH}$ stimulation was able to increase the $\mathrm{B} / \mathrm{I}$ ratio only in $C D$, this response may require priming of the pituitary by previous GnRH pulses. Such priming was evidently missing in the $\mathrm{HH}$ group.

However, when the F-LH measurements are taken into account, the meaning of the pubertal and post-GnRH increases in the $B / I$ ratios may have to be reevaluated. When the concentrations measured were in the optimal range of $\mathrm{B}-\mathrm{LH}$ measurements $(>1 \mathrm{IU} / \mathrm{L})$, the $\mathrm{B} / \mathrm{F}$ ratios neither differed between the $\mathrm{CD}$ and $\mathrm{HH}$ groups nor increased in the CD group after GnRH stimulation. An explanation to the discrepancies between the $B / I$ and $\mathrm{B} / \mathrm{F}$ ratios is that RIA overestimates low $\mathrm{LH}$ levels, because of its low sensitivity and of cross-reactions with free LH subunits and/or other, as yet unidentified, constituents of serum. The FLH measurements in contrast detect only intact LH molecules with high specificity and sensitivity. Hence, the correlation of BLH levels is better with F-LH than with I-LH. When the LH levels increase (with advancing puberty or after $\mathrm{GnRH}$ ), the real increase in immunoreactive $\mathrm{LH}$ is greater than that measured by $\mathrm{I}-\mathrm{LH}$, hence resulting in erroneous increase of the $\mathrm{B} / \mathrm{I}$ ratio. In contrast, also the low levels of F-LH are correct and no change in the $B / F$ ratio is seen during $\mathrm{GnRH}$ stimulation. In the $\mathrm{HH}$ group, the basal B-LH levels are overestimated because of insufficient sensitivity of this assay, and now the B/F ratio decreases when the B-LH levels reach the optimal range of the bioassay after GnRH. Our present data suggest therefore that the meaning of the $\mathrm{B} / \mathrm{I}$ ratios reported in the past may have to be reevaluated using the specific and sensitive methods of detection of $\mathrm{LH}$ immunoreactivity.

In conclusion, our present data demonstrate the potential advantage of B-LH and F-LH measurements in the differential diagnostics of delayed puberty in boys. In addition, our results point out a possible problem in the calculations of the bio/ immuno ratios using conventional immunoassay methods.

Acknowledgment. The skillful technical assistance of Ms. Aila Metsävuori is gratefully acknowledged.

\section{REFERENCES}

1. Styne DM, Grumbach MM 1986 Puberty in the male and female. Its physiology and disorders. In: Yen SSC, Jaffe RB (eds) Reproductive Endocrinology, 2nd ed. WB Saunders, Philadelphia, pp 313-384

2. Rudd BT 1988 Precocious and delayed sexual development in children. Acta Endocrinol (Copenh) 119(suppl 288):66-76

3. Razdan AK, Fang VS, Rich BH, Britton H, Rosenfield RL 1979 Gonadotropinreleasing hormone infusion test in the distinction of hypopituitary patients from normal subjects. Fertil Steril 31:507-512

4. Chaussain JL, Garnier PE, Binet E, Vassal J, Scholler R, Job JC 1974 Effect of synthetic luteinizing hormone-releasing hormone (LHRH) on the response of gonadotropins in hypophyso-gonadal disorders of children and adolescents. III. Hypopituitarism. J Clin Endocrinol Metab 38:58-63
5. Dunkel L, Perheentupa J, Virtanen M, Mäenpää J 1985 GnRH and HCG tests are both necessary in differential diagnosis of male delayed puberty. Am $\mathrm{J}$ Dis Child 139:494-498

6. Lucky AW, Rich BH, Rosenfield RL, Fang VS, Roche-Bender N $1980 \mathrm{LH}$ bioactivity increases more than immunoreactivity during puberty. J Pediatr 97:205-213

7. Reiter EO, Beitins IZ, Ostrea T, Gutai JP 1982 Bioassayable luteinizing hormone during childhood and adolescence and in patients with delayed pubertal development. J Clin Endocrinol Metab 54:155-161

8. Rich BH, Rosenfield RL, Moll Jr GW, Lucky AW, Roche-Bender N, Fang V 1982 Bioactive luteinizing hormone pituitary reserves during normal and abnormal male puberty. J Clin Endocrinol Metab 55:140-146

9. Marrama P, Zaidi AA, Montanini V, Celani MF, Cioni K, Carani C, Morabito F, Resentini M, Bonati B, Baraghini GF 1983 Age and sex related variations in biologically active and immunoreactive serum luteinizing hormone. $\mathbf{J}$ Endocrinol Invest 6:427-433

10. Montanini V, Celani MF, Baraghini GF, Carani C, Marrama P 1984 Effects of acute stimulation with luteinizing hormone-releasing hormone (LRH) on biologically active and immunoreactive serum luteinizing hormone $(\mathrm{LH})$ in pubertal boys. Acta Endocrinol (Copenh) 107:289-294

11. Burstein S, Schaff-Blass E, Blass J, Rosenfield RL 1985 The changing ratio of bioactive to immunoreactive luteinizing hormone (LH) through puberty principally reflects changing $\mathrm{LH}$ radioimmunoassay dose-response characteristics. J Clin Endocrinol Metab 61:508-513

12. Reiter EO, Biggs DE, Veldhuis JD, Beitins IZ 1987 Pulsatile release of bioactive luteinizing hormone in prepubertal girls: discordance with immunoreactive luteinizing hormone pulses. Pediatr Res 21:409-413

13. Beitins IZ, Axelrod L, Ostrea T, Little R, Badger TM 1981 Hypogonadism in a male with an immunologically active, biologically inactive luteinizing hormone: characterization of the abnormal hormone. J Clin Endocrinol Metab 52:1143-1149

14. Veldhuis JD, Johnson ML, Dufau ML 1987 Preferential release of bioactive luteinizing hormone in response to endogenous and low dose exogenous gonadotropin-releasing hormone pulses in man. J Clin Endocrinol Metab $64: 1275-1282$

15. Wennink JMB, Delemarre-van de Waal HA, van Kessel H, Mulder GH, Foster JP, Schoemaker J 1988 Luteinizing hormone secretion patterns in boys at the onset of puberty measured using a highly sensitive immunoradiometric assay. J Clin Endocrinol Metab 67:924-928

16. Apter D, Cacciatore B, Alfthan H, Stenman U-H 1989 Serum luteinizing hormone concentrations increase 100-fold in females from 7 years of age to adulthood, as measured by time-resolved immunofluorometric assay. J Clin Endocrinol Metab 68:53-57

17. Zachmann M, Prader A, Kind HP, Häflinger H, Budliger H 1974 Testicular volume during adolescence. Cross-sectional and longitudinal studies. Helv Paediatr Acta 29:61-72

18. Greulich WW, Pyle SI 1955 Atlas of Skeletal Development of the Hand and Wrist. Stanford Univ Press, Palo Alto, CA

19. Tanner JM 1962 Growth at Adolescence, 2nd ed. Blackwell, Oxford, p 32

20. van Damme M-P, Robertson DM, Diczfalusy E 1974 An improved in vitro bioassay method for measuring luteinizing hormone (LH) activity using mouse Leydig cell preparations. Acta Endocrinol (Copenh) 77:655-671

21. Ding Y-Q, Huhtaniemi I 1989 Human serum LH inhibitor(s): behaviour and contribution to in vivo bioassay of LH using dispersed mouse Leydig cells. Acta Endocrinol (Copenh) 121:46-54

22. Huhtaniemi I, Nikula H, Rannikko S 1985 Treatment of prostatic cancer with a gonadotropin-releasing hormone agonist analog: acute and long term effects on endocrine functions of testis tissue. J Clin Endocrinol Metab 61:698-704

23. Veldhuis JD, Beitins IZ, Johnson ML, Serabian MA, Dufau ML 1984 Biologically active luteinizing hormone is secreted in episodic pulsations that vary in relation to stage of the menstrual cycle. J Clin Endocrinol Metab 58:10501058

24. Dufau ML, Beitins IZ, McArthur JW, Catt KJ 1976 Effects of luteinizing hormone releasing hormone (LHRH) upon bioactive and immunoreactive serum LH levels in normal subjects. J Clin Endocrinol Metab 43:658-667

25. Veldhuis JD 1987 Contemporary insights into the regulation of luteinizing hormone secretion in man. Hormone Res 28:126-138

26. Spitz IM, Diamant Y, Rosen E, Bell J, David MB, Polishuk W, Rabinowitz D 1974 Isolated gonadotropin deficiency: a heterogeneous syndrome. N Engl J Med 290:10-15

27. Boyar RM, Wu RHK, Kapen S, Hellman K, Weitzman ED, Finkelstein JW 1976 Clinical and laboratory heterogeneity in idiopathic hypogonadotropic hypogonadism. J Clin Endocrinol Metab 43:1268-1275

28. Warner B, Worgul TJ, Drago J, Demers L, Dufau M, Max D, Santen RJ 1983 Effect of very high dose D-leucine ${ }^{6}$-gonadotropin-releasing hormone proethylamide on the hypothalamic-pituitary testicular axis in patients with prostatic cancer. J Clin Invest 71:1842-1853

29. Evans RM, Doelle GC, Lindner J, Bradley V, Rabin D 1984 A luteinizing hormone-releasing hormone agonist decreases activity and modifies chromatographic behavior of luteinizing hormone in man. $\mathrm{J}$ Clin Invest 73:262266

30. StArnaud R, Lachance R, Dupont A, Labrie F 1986 Serum luteinizing hormone ( $\mathrm{LH}$ ) biological activity in castrated patients with cancer of the prostate receiving a pure antiandrogen and in estrogen-pretreated patients treated with an LH-releasing hormone agonist and antiandrogen. J Clin Endocrinol Metab 63:297-302 